\title{
Osteoma em côndilo mandibular associado à síndrome de gardner: relato de caso
}

\author{
Osteoma in mandibular condyle associated with gardner syndrome: a case report \\ Cristina Balensiefer Vicenzi ${ }^{1, a}$, Milena Giotti Marostega ${ }^{1, a}$, Renato Sawazaki ${ }^{2, b}$, Ferdinando de Conto ${ }^{3, c}$.
}

\section{RESUMO}

Os osteomas geralmente são lesões solitárias, de crescimento lento e assintomáticas. Os locais de ocorrência mais comuns são o corpo da mandíbula e o côndilo, mas quando envolvem esta região podem causar alterações na oclusão do paciente, desvio progressivo e lento de linha média, assim como aumento do volume facial acompanhado de dor e limitação de abertura bucal. Cerca de $90 \%$ dos pacientes portadores da Síndrome de Gardner apresentam anormalidades esqueléticas, fazendo os osteomas as lesões mais frequentes e de maior ocorrência em seios paranasais e nos maxilares. O objetivo deste trabalho é relatar o caso clínico de uma paciente do gênero feminino, portadora de Síndrome de Gardner com osteoma localizado em côndilo mandibular esquerdo que, devido aos sintomas relatados pelo paciente, foi submetida à ressecção cirúrgica por meio de acesso intra oral para melhor abordagem da lesão e que evoluiu para a solução da sintomatologia apresentada como queixa principal quando procurou o serviço de Cirurgia e Traumatologia Buco-maxilo-facial.

\section{PALAVRAS-CHAVE: Osteoma, Síndrome de Gardner, Côndilo mandibular (DeCS)}

\section{SUMMARY}

Osteomas are usually solitary, slow-growing and asymptomatics lesions. The most common sites of occurrence are condyle and jaw body. Osteomas involving condyle can cause changes in patient's occlusion, progressive and slow deviation of the midline, as well as increased facial volume accompanied by pain and limited mouth opening. An osteoma located in mandible border is typical of the Gardner's Syndrome. There are many clinical features of this syndrome, which can affect the skin, endocrine system and orofacial area. About $90 \%$ of patients with this condition have skeletal abnormalities, making osteomas the most frequent lesions in the paranasal sinuses and jaws. The objective of this work is to report the clinical case of a female patient with Gardner's Syndrome with osteoma located in the left mandibular condyle, who was submitted to resection of the lesion.

\section{KEY WORDS: Osteoma, Gardner Syndrome, Mandibular condyle.}

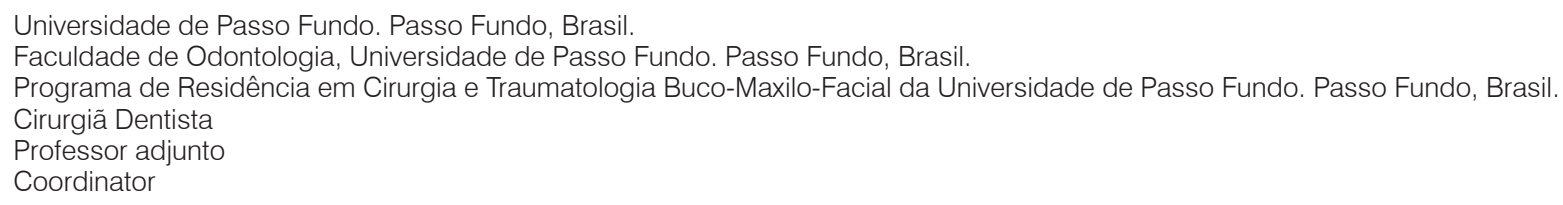




\section{INTRODUCTION}

Benign and slow growing tumors, composed by mature bones (either compact or cancellous) are called osteomas. Its growing is essentially restricted to the skull facial skeleton, for they are rarely found in other types of bones. They are, usually, asymptomatic and solitary lesions with a slow growth process, and the region most frequently affected are the mandible body and the condylar process (1).

In a general way, this pathology is diagnosed at different ages, presenting a higher prevalence within adults older than 30 years old. Depending on the region of its growth, as it is a proliferation of compact or cancellous bone, it can be classified in endosteal osteoma (found in the medullar zone) or periosteum osteoma (found superficially to the bones)(2).

The identification of osteomas, in the maxillofacial region, can be the clinical finding that can guide to the Gardner Syndrome, a disease with several manifestations which can affect the skin, the endocrinal system and the oral-facial area. Due to the big variations of its clinical features, it can make the diagnosis difficult to be made. An osteoma found in the mandible base is a typical manifestation of the Gardner Syndrome. The objective of this article is to relate a clinical case of a female patient, carrier of Gardner Syndrome, with an osteoma situated in the left mandible condylar process, which was submitted to the resection.

\section{Case report}

A 25-years-old female patient arrived at the buco-maxillo-facial surgery and traumatology residency service reporting severe pain at the region of the temporomandibular joint and left mandibular ramus. She said that it had started in the past 90 days. Before it, she was painless. Also, the patient informed that, about 15 years ago, an infiltration was performed in that joint, which caused the pain to reduce by $50 \%$ until she evolved, over the years, to no pain. Besides that, she noticed a slow and progressive change of dental occlusion, as well as the craniomandibular dysfunction. The anamnesis revealed that the patient also had multiple intestinal polyps confirmed in previous colonoscopies (figure 1), and that she had a history of mandibular osteoma follow-up since she was 15 years-old. The patient had already been, even, sub- mitted to surgery to remove the local mandible lesion (time that she was diagnosed with the Gardner Syndrome). To control it, she used to do periodic panoramic radiographic exams and a complete monitoring of the intestinal polyps and the subcutaneous lesions that she presented.

By the physical examination, it was possible to observe, upon palpation, a mandibular surface alteration throughout its whole body, bilaterally. The computed tomography showed a circumscribed sclerotic mass of approximately $8 \mathrm{~mm}$ in the medial pole of the mandible head and, also, multiple radiopaque foci compatible with osteomas. With these clinical findings, the diagnosis of Gardner Syndrome was, again, confirmed (figure 2).

Once considered the symptomatology in the left temporomandibular joint region, it was optioned for surgical removal of the lesion located in the medial pole of the mandibular head, with general anesthesia, through an intraoral approach to the ascending mandibular ramus (the same local used for the sagittal mandible osteotomy technic, often used in orthognathic surgeries). For the lesion resection, a drill and a chisel were used (figure 3 ). The specimen was submitted to histopathological examination, which confirmed the diagnosis of osteoma.

The patient remained in postoperative clinical and radiographic follow-up, for 12 months, without presenting recurrence or any alteration (figure 4). 

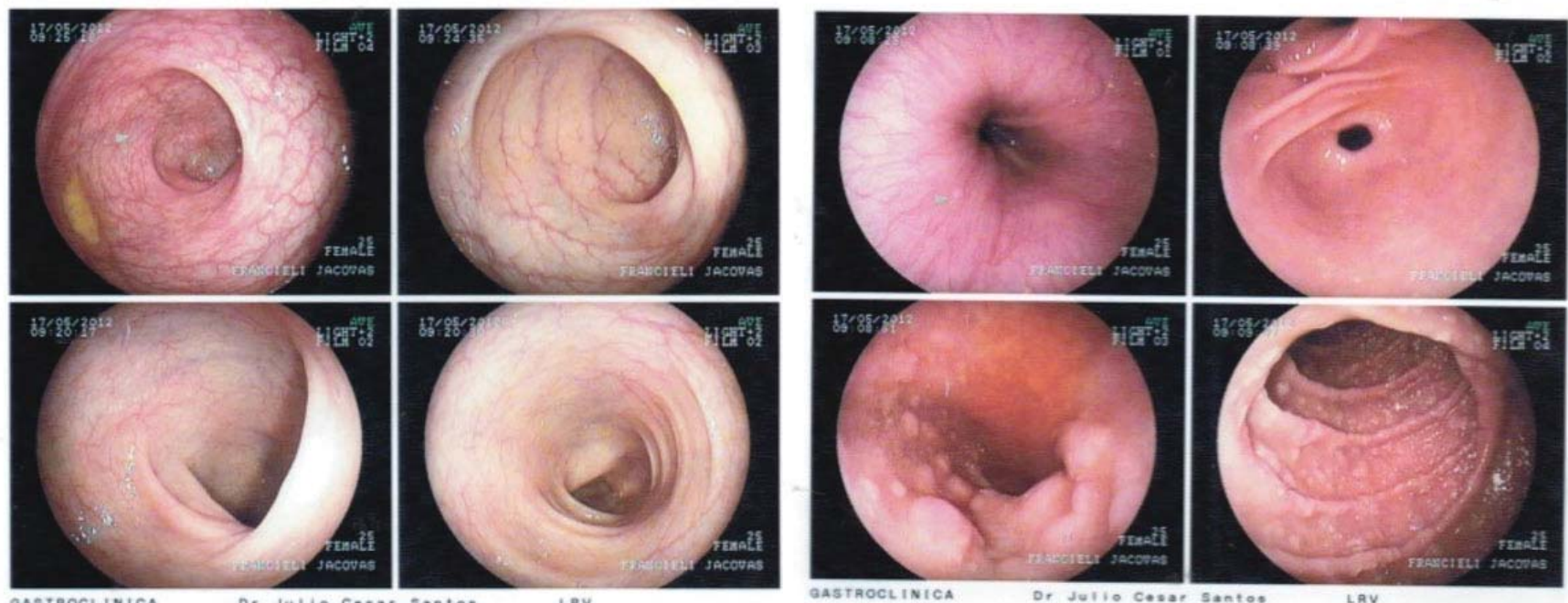

GASTROCLINICA

Dr Juito cosur santos

aATHOCLINICA

Dr Jurio ceser santos

Lav
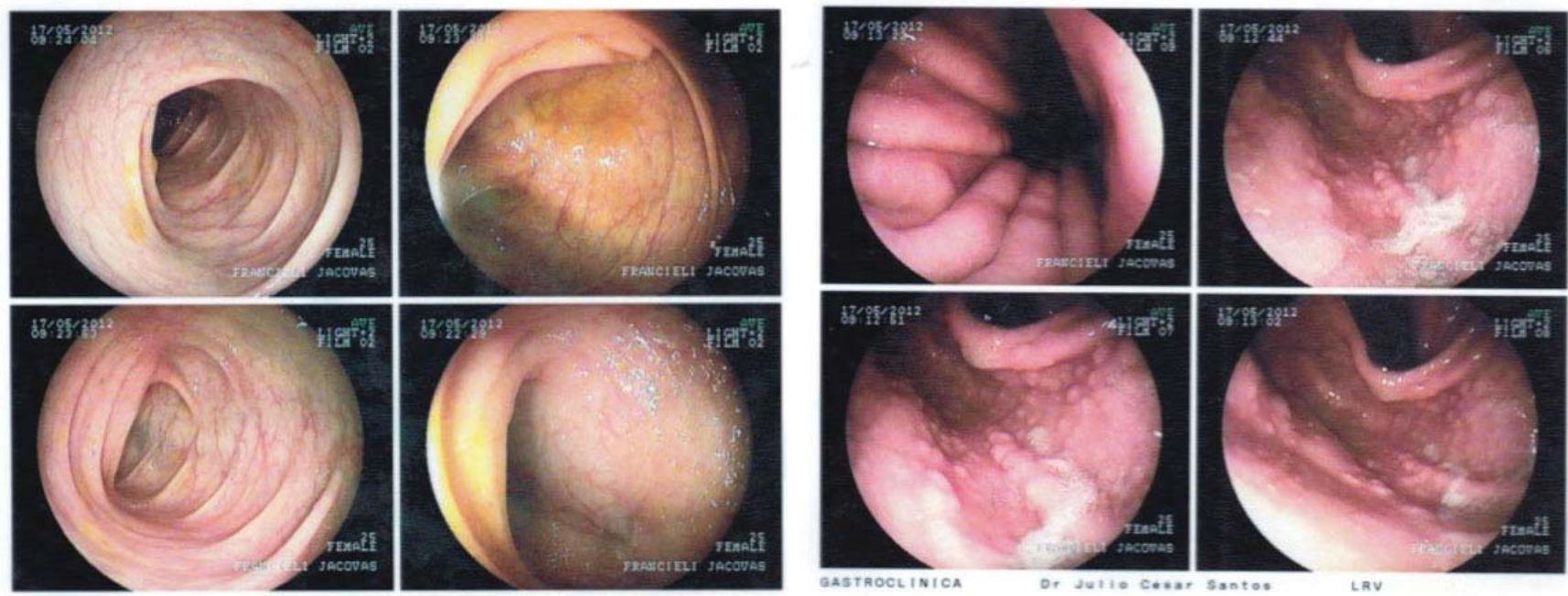

Figure 1. Endoscopic examination presenting multiple intestinal polyps.
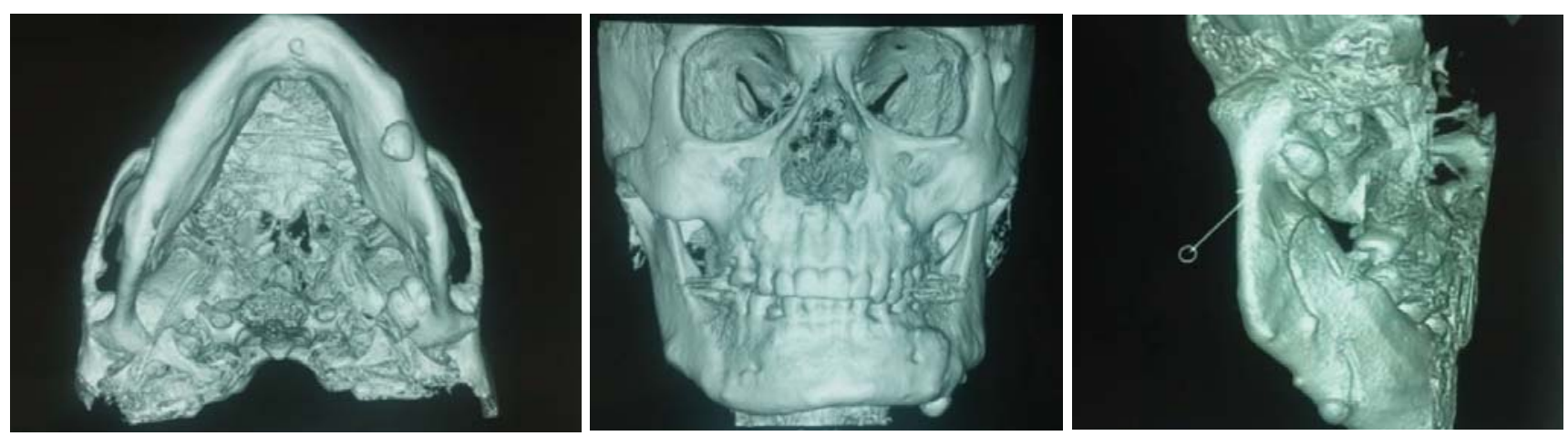

Figure 2. Volumetric cone beam computed tomography reconstruction, demonstrating bone lesions at the base and mandibular condyle. 

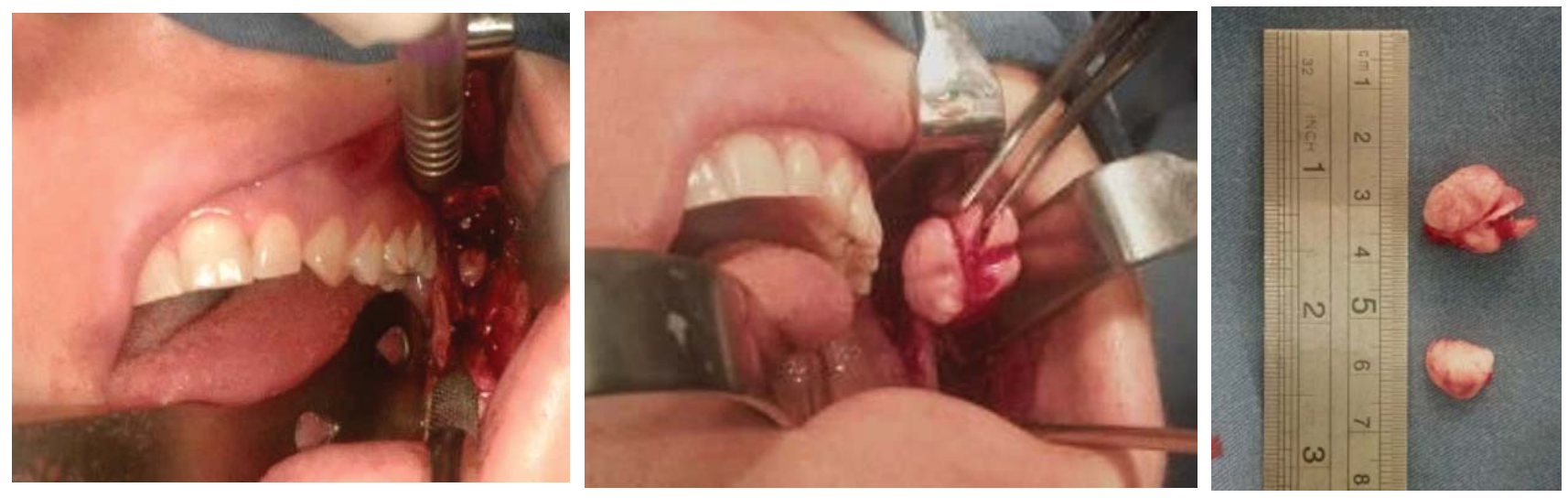

Figure 3. Injury intraoral access removal.
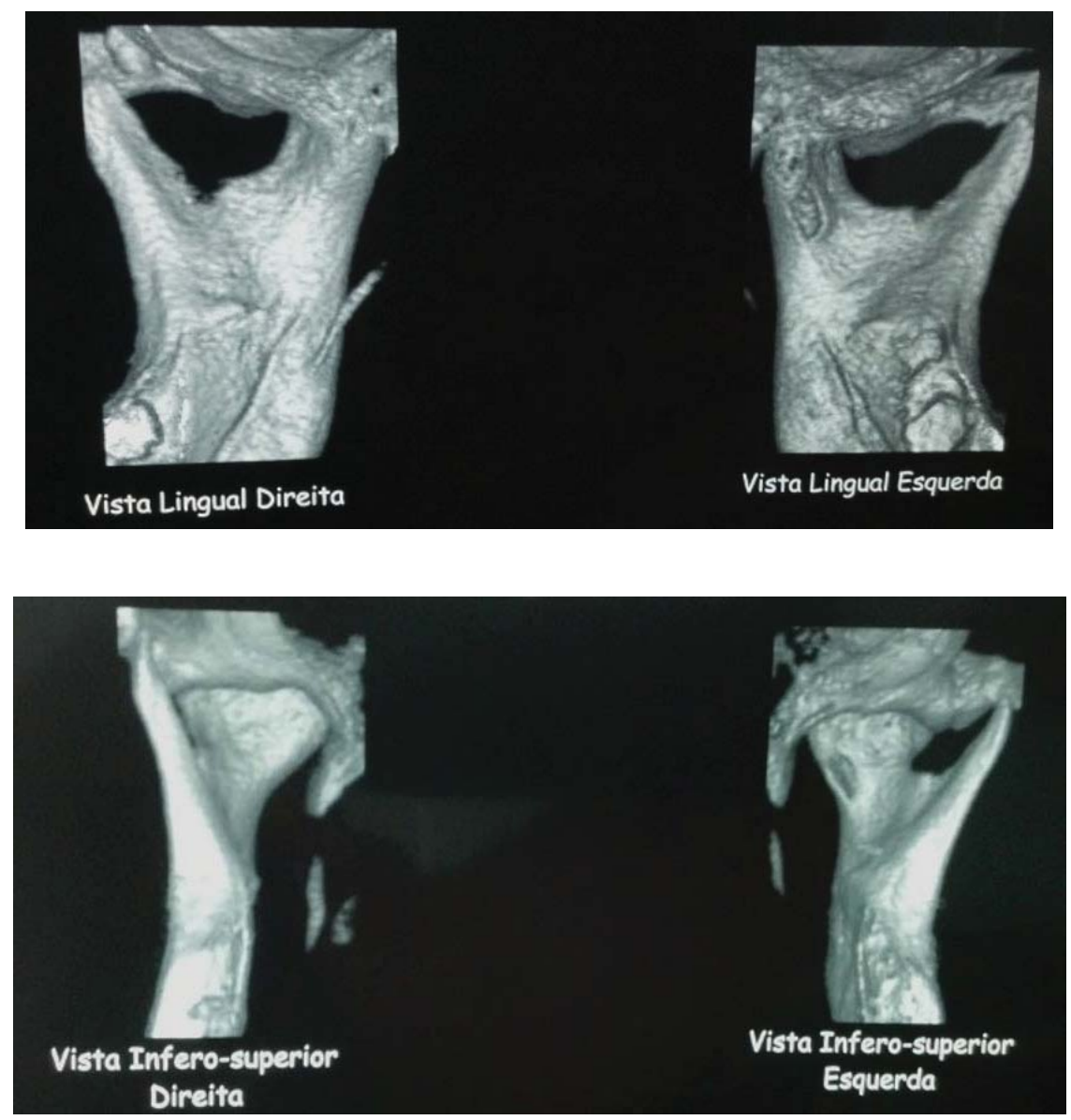

Figure 4. Cone beam computed tomography images, after 6 months of the condylar lesion surgical removal, for postoperative follow-up. 


\section{DISCUSSION}

Osteoma can be locally aggressive with compression and invasion of adjacente structures, mainly orbital structures and skull base. When sintomatics, it can cause headache, nasal obstruction, vision changes, facial pain and facial asymmetry (3). Its etiology isn't well understood, suggesting that it may originate at boné growth intensification (puberty), infectious factors, hereditary factors, traumatic factors or even increased activity of periosteal osteoblastos $(4,5)$.

Osteomas involving mandible condyle may cause changes in the patient's occlusion, progressive and slow deviation of the midline, as well as increased facial volume accompanied by pain and limited mouth opening (6).

Gardner's Syndrome is an autosomal dominant disease of the colon characterized by the presence of numerous polyps (7). About $90 \%$ of patients with Gardner's Syndrome have skeletal abnormalities, making osteomas the most frequente lesions in the paranasal sinuses and jaws.

Early detection of Gardner's Syndrome is extremely important, as patients may develop colorectal adenocarcinoma. Maxillofacial features of the syndrome may appear years before intestinal polyposis, so dentists should be familiar with the importance of this pathological condition as a precancerous lesion. The presence of multiple bone changes of the skull and dental and skeletal abnormalities should alert the clinician to initiate an investigation (8).

The impaction of teeth, odontomas and supernumerary elements may also be associated with these lesions, with a prevalence of $20 \%$ of patients with the Gardner's Syndrome (9).

The diagnosis is realized with the patient's clinical examination and complementary exams such as $\mathrm{x}$-rays and computed tomography, being the best option for the diagnosis of this lesion. Usually, they are solitary lesions, being evidenced in examinations like a single, regular mass, with bone density and well circumscribed $^{8}$. Radiographically, these lesions present as a well defined radiopaque image, presenting a uniform sclerotic pattern. These lesions resemble radiographically with other pathologies, such as ossi- fying fibroma, fibrous dysplasia, osteoid osteoma and idiopathic sclerosis (10).

Literature reports refer to different conditions such as limiting mouth opening, as well as reaching a considerable size causing disfiguration. In this case report, the patient had an opening limitation, however, there was no facial deformity (9).

Removal of osteomas is not necessary in all cases. When the lesion is symptomatic or active growth, surgery is indicated and the surgical approach depends on each specific case. Extensive osteomas causing symptoms and facial deformity can be treated with conservative surgical excision, as the tendency for relapse is small after adequate resection. In the case of mandibular lesions, the approach can be performed intra-oral or extra-oral $(4,11)$.

As an imaging exam, the peripheral osteoma can be evidenced by panoramic radiography or by computed tomography. For greater accuracy of localization and better resolution of the lesion, the use of Volumetric reconstruction and Computed tomography cone beam can aid in the diagnosis (12).

Cone-beam computed tomography (CBCT) has been introduced in the diagnosis of images in the various areas of dentistry as a digital, three-dimensional method that provides isometric images in the three planes. TCCB involves less exposure to radiation and its cost is lower compared to conventional computed tomography (13). Among their indications, we can highlight the planning of impacted teeth extraction, evaluation of temporomandibular joints, in orthodontic, endodontic and dental implant planning, evaluation of maxillofacial pathological conditions and also in cases of dentoalveolar fractures, to improve the diagnosis and define the surgical approach (12).

The choice of the approach should take into account, especially the size, location and extent of the lesion (11). Whenever possible, the intra-oral approach is preferable, due to aesthetic reasons. In this clinical case, the choice of surgical access was even more supported by the location of the lesion, since, although it is more difficult to approach the TMJ region by intraoral, the conventional accesses of this area of the mandible are extra-oral but offer a view lateral aspect of the mandible, but the lesion was located just at the medial pole of the condyle. Condilectomy is indica- 
ted for the treatment of extensive osteomas. When submitted to this type of treatment, reconstruction of the mandibular condyle may be necessary (6).

Injuries of smaller diameter and asymptomatic, do not require surgical treatment, being instructed the accompanied periodic of the injury (14). The differential diagnosis for osteomas includes bone exostoses, fibrous osteoma, giant cell tumors, fibrous dysplasia, torus and mucoceles in the maxillary sinuses (15).

Osteomas may go unnoticed because they are asymptomatic in most cases, or even receive conservative treatment. In the presented clinical case, the surgical treatment was chosen due to the symptoms reported by the patient. The chosen intra-oral access proved to be an excellent choice due to the location of the lesion and its size. Differential diagnosis of the lesion is necessary, even for a possible association with Gardner's Syndrome, in view of its other clinical repercussions, as well as the long-term follow-up.

Therefore, a detailed and complete diagnosis of the patient as a whole, including his systemic health, is necessary. In this way, by directing him to the necessary treatment, preventing possible facial asymmetry and patient discomfort.

\section{Correspondência:}

Cristina Balensiefer Vicenzi

e-mail: crisvicenzi@gmail.com

\section{REFERENCES}

1. Caubi AF, Moura RQ, Borba PM, Costa DFN, Bispo LMM. Osteoma em mandíbula: quando trata-lo cirurgicamente. Rev Cir Traumatol Buco-Maxilo-Fac. 2013; 13(1): 53-58.

2. Cesa TS, Della Giustina JC, Silva AF, Dissenha JL, Sassi LM. Osteoma of the mandible: a case report. Rev. Cir. Traumatol. Buco-Maxilo-fac. 2013; 13(1): 59-63.

3. Balieiro FO, Bordash A, Stamm AEC, Sebusiani BB, Filho ISB. Paranasal sinus osteomas: Diagnosis and treatment. Rev Stomatol Chir Maxillofac Chir Orale. 2016; 117(5): 306-310.

4. De Conto F, Cardoso MZ, Toledo MCD, Rhoden R, Rovani G, Flores ME. Osteoma periférico em ángulo mandibular: relato del caso. Odontoestomatologia. 2013; 15 (22): 64-70.

5. Al-Yahya SNSH, Hamizan AKW, Zainuddin N, Arshad AI, Ismail F. Mastoid osteoma: report of a rare case. Egyptian Journal of Ear, Nose, Throat and Allied Sciences. 2015; 16(2): 189-191.

6. Hoyos ZMO, Garcia RF, Pérez AR, Garza CM. Osteoma central em côndilo mandibular. Tratamiento: Reporte de um caso. Revista Mexicana de Cirugía Bucal y Maxilofacial. 2010; 6(2): 61-65.

7. Koh K, Park H, Kim K. Gardner syndrome associates with multiple osteomas, intestinal polyposis, and epidermoid cysts. Imaging Sci Dent. 2016; 46(4): 267-272.

8. Gawande P, Deshmukh V, Garde JB. A Giant Osteoma of the Mandible. J Maxillofac Oral Surg. 2015; 14(2): 460-465.

9. Adisen MZ, Okkesim A, Misirlioglu M. The importance of early diagnosis of gardner's syndrome in dental examination. Niger J Clin Pract. 2018; 21: 114-116.

10. Boros LF, Carneiro MIS, Boros LH, Boros PAS. Osteoma Compacto Central de Mandíbula: relato de caso clínico. Odontol. Clín-Clent. 2011; 10(1): 89-93.

11. Arslan HH, Tasli H, Cebeci S, Gerek M. The management of the paranasal sinus osteomas. J Craniofac Surg. 2017; 28 (3): 741-745.

12. Wenzel A, Hirsch E, Christensen J, Matzen LH, Scaf G, Frydenberg M. Detection of cavitated approximal surfaces using cone beam CT and intraoral receptors. Dentomaxillofacial Radiology. 2013; 42(1): 1-5

13. Friedrich RE, Fraederich M, Schoen G. Frequency and volumetry of infraorbital ethmoid cells (Haller cells) on cone-beam computed tomograms (CBCT) of the mid-face. GMS Interdisciplinary Plastic and Reconstructive Surgery. 2017; 6: 1-9.

14. Boffano P, Roccia F, Campisi P, Gallesio C. Review of 43 Osteomas of the craniomaxillofacial region. J Oral Maxillofac Surg. 2012; 70: 1093-1095.

15. Lino J, Monteiro D, Carvalho I, Pinto Ferreira J, E de Almeida e Sousa C. Osteoma gigante de seio frontal A propósito de um caso clínico. Revista Portuguesa de Otorrinolaringologia e Cirurgia Cervico-Facial. 2015; 52(4): 239-242. 